Literacy abilities in students - an essential element in the formation of the learning to learn competence

Nicoleta Meseșan 


\title{
Literacy abilities in students - an essential element in the formation of the learning to learn competence
}

\author{
Nicoleta Meseșan ${ }^{\text {** }}$ \\ ${ }^{a}$ Doctoral School "Educational, Reflection, Development", Babeş-Bolyai University, 7 Sindicatelor Street, 400029, Cluj-Napoca, Romania \\ *Corresponding author: nicoletamese@yahoo.com
}

Abstract

Keywords: literacy abilities, learning to learn, lifelong learning
The dynamics of current society urges and obliges to an easy and quick adaptation at the same time. The Parliament and the European Comission have recommended that until the end of mandatory schooling, all students from all of the member states of the EU should form eight essential key-competences for a lifelong learning. Learning to learn is one of the eight key-competences and it implies the formation in students of some learning abilities during mandatory schooling so that they might be able, in the future, to be connected constantly to the novelties of the professional and social field in which they activate. In the formation and development of the aforementioned competence, literacy abilities are a key-element. Reading, comprehension and the transposition of the received information from a literary or a scientific text into a new context constitute essential stages in the formation of the learning to learn competence.

Taking into consideration the importance of the formation of the literacy abilities in the schooling, profesional and social evolution of the students, the current study wishes to present the results of a micro-research that was done on the level of the formation of these abilities at the end of the mandatory schooling stage in the Romanian educational system. The study was done on four classes of students, from the 10th grade, from two different highschools, with a pedagogical vocational orientation, the teacher-educator specialization.

In the formation of the learning to learn competence, directed learning and individual study contribute to a large extent and the literacy abilities are the foothold in the realization of an efficient learning.
Zusammenfasung

Schlüsselworte: Literalität; Lernen lernen; lebenslanges Lernen
Der gegenwärtige Artikel ist eine qualitative Forschung, vorhabend, auf die folgende Frage zu antworten: "Was betrachtet die Ansicht von Eltern die Integration der Studenten mit speziellen Bedürfnissen in Hauptströmungsschulen?", um auf diese Frage zu antworten, wurde die Gruppeninterview-Methode beschäftigt(eingesetzt). Die Fokus-Gruppe wurde von zehn Beklagten, Eltern der typischen Studenten einer städtischen Schule am niedrigeren Niveau der höheren Schule aufgewartet. Die Resultate zeigten eine positive Haltung Leuten mit Körperbeschädigungen im allgemeinen, aber dem Grad der Toleranz und Annahme der Eltern-Abnahmen, wenn es zu Integrierung von Studenten mit speziellen pädagogischen Bedürfnissen mit ihren eigenen Kindern kommt. Die Gegebenheiten(Daten) gingen durch Inhaltsanalyse in einer Prozession ist ein Ausgangspunkt für zukünftige Forschung in die Gemeinschaft-Haltungen zur Einbeziehung der Studenten mit speziellen Bedürfnissen.

\section{Introduction}

In a society with quick and diverse changes in all fields of activity, adaptation and the ozitive answer to the current professional and social challenges can only be obtained by forming some abilities and competences during schooling, which should constitute the operational support for continuous learning and adaptation. In the 21 st century education, the emphasis must be moved from how much the student knows - the quantity of accumulated knowledge - to what the student knows how to do, so on abilities and competences, on the ability to put the knowledge into practice. "The emphasis is put on offering the children indispensable tools of knowledge for the intellectual formation and methods of independent work that are necessary to the completion of the training that was received in school" (Albulescu, 2008, p.18).

The European Council and Commission have recommended that during mandatory schooling, the students should acquire eight key-competences to represent the basis of future social and professional activity, for a lifelong learning. These competences are: communication in a maternal language, communication in a foreign language, a mathematical, scientific and technological competence, digital competence, learning to learn, social and civic competences, having an initiating and entrepreneurial spirit, cultural sensibilization and expression (Recommendation of the European Parliament and Council - 2006/962/CE 
regarding the key-competences for a lifelong learning (https://eur-lex.europa.eu/legal-content/RO/). The keycompetences "represent a transferrable and multifunctional package of competences that must be developed until the end of mandatory schooling" (Bocoș, (coord.), 2016, p. 223) for the adaptation of the person in a flexible way to a world that is constantly changing.

The competence of learning to learn is important because there is no particular discipline that contributes to the formation of this competence in students, and since it's transversal, like all key-competences, it must be attained using applied strategies on all disciplines of study during mandatory schooling.

The preoccupation of the teachers for improving learning in schools as a process, but also as a product is constant. Specific action is continuously unfolded for the development of the curriculum and strategies destined for students in order to increase school performance so that the future graduates may become competitive on the labor market and the integration in society may take place quickly and actively. The formation of the learning abilities is essential, and literacy has an important place in the learning activity.

\section{Theoretical foundation}

Between the necessary competences that should be developed in students during mandatory schooling, at the recommendation of the European Parliament and Council, we can also find the learning to learn field of competence. Even though none of the eight keycompetences isn't considered to be more important that the others, since all have an essential role in forming youngsters for a social and professional insertion, learning to learn can be considered an integrative competence. This competence includes the awareness of one's own learning process and needs, the identification of the available opportunities and the ability to overcome the obstacles for a succesfull learning. Learning to learn is a complex competence that can be used both from the point of view of the student, as well as the point of view of the teacher. Regarding the student, he forms his learning strategies during the formal education, a period of time in which he assimilates basic knowledge that is specific to various disciplines, he manifests different attitudes towards learning, he learns certain behaviors that are specific to school or society. During this time, the student also has the opportunity to be evaluated and to evaluate himself. This will help him to become aware of his development needs, the fields that are well contoured or that require greater attention and where he's on track to achieve his goals. These aspects are also motivational factors that support the need to learn. Initially, the student follows the steps that are presented by the teacher, adding personal data based on self-knowledge, on the understanding of one's own mechanism of assimilating knowledge.

From the teacher's point of view, an essential constribution to the formation of an effective style of learning can be noticed. Effective learning can be described in the following manner: in a short time, with balanced resources, to obtain maximum performance. The teacher must explain to the students what are the necessary steps that they can and must take in order to achieve their goals, the manner in which they can establish realistic objectives and, also, how they can be persistent in achieving their goals and valuing cognitive aquisitions in new life and/or learning situations.

Firstly, the learning abilities include the capability of the student to operate with written text. We call this ability literacy. Literacy is defined by the OECD (The Organization for Economic Cooperation and Develoment) as "the aptitude of understanding and using written information in daily life, at home, in the working environment, so that the person may be able to achieve certain personal goals and to develop his knowledge and abilities" (OECD, 2000). In the British Encyclopedia, literacy is defined as the ability to communicate using signs or written, printed or electronic symbols that are reprezentative for the language (https://www.britannica.com/search?query=literacy).

The formation of these abilities isn't just necessary, but also compulsory in a society where writing offers and important means of communication and also a resource for knowledge. Why are literacy abilities necessary in a society dominated by technology? Writing is the essential way of transmitting and receiving messages. The formation in students of the ability to select information from a text and apply it in new situations represent a basic ability in a society of knowledge. Reading has many levels: basic reading, inspectional reading, analytical reading (Adler \& Van Doren, 2014) and each level makes the reader more advanced. 
In the same paper there are presented methods of studying different types of text: literary, scientifical, philosophical texts etc., each having difficulties, but also particular methods of approach.

Taking into consideration the complexity of the learning to learn competence, the development of literacy abilities in students during mandatory schooling is stringently necessary. Literacy can be described in components that are correlated in a system according to functionality: a) desciphering and using information from the written text, b) integrating the information in the structure of the previous knowledge and c) tansposing the information in practical-applicative situations, in problem solving or in finding some innovative solutions to current or special cases from the school, profesional or social activity.

The formation of literacy abilities is an issue which concerns specialists from all current educational systems, because in this way functional illiteracy will be eliminated. Currently, illiteracy affects the school population in different proportions in each of the member states of the EU. In Romania, functional illiteracy reaches alarming peaks, especially in the field of receiving the written message. In the case of the PISA tests, the results show that $35 \%$ of Romanian students are on the 2 nd level. Under level 2, meaning on the lvel $1 \mathrm{a}, 1 \mathrm{~b}$ and below $1 \mathrm{~b}$ are $38,6 \%$ of the students. Cummulatively, on the higher levels $-3,4$ and 5 - are $27,5 \%$ of the Romanian students" (https://www.edu.ro/rezultatele-elevilorrom $\% \mathrm{C} 3 \% \mathrm{~A} 2$ ni-la-testarea-oecd-pisa-2015). The 2nd level is the basic level which must be reached at the end of the mandatory studies so that a 15 year old youngster may be able to continue his studies efficiently or to be integrated on the labor market.

Therefore, the necessity of forming the literacy abilities is emphasized both from the point of view of preventing functional illiteracy, as well as the formation of the learning to learn key-competence for a lifelong learning.

\section{Research methodology}

Taking into consideration the presented issues, it was considered useful and important to follow the level of the literacy abilities in students that are at the end of mandatory schooling, on the 10th grade. The research tool that was used was the survey. Through this survey, there were analyzed aspects related to the study techniques of literary and scientific texts, the difficulties encountered by the students when studying scientific texts, as well as the difficulties in learning in school, but also the level of acknowledgement in students of the need to form studying techniques of the scientific texts. In the construction of the survey, the term learning techniques was used, and not that of literacy, in order to ensure the familiariation and familiarity of the students with the terminology that was used.

The survey was applied on a group of students that was selected out of 10th grade students, two different vocational high schools, pedagogical profile, the specialty teacher-educator, from Sibiu and Cluj-Napoca. In this way, the working group constituted of 115 subjects from four grades, each two from every school unit.

The survey that was applied is considered a useful tool for analyzing the issue of literacy abilities for literary and scientific texts, the necessity of forming studying techniques of the text, as well as the difficulties encountered by students when studying scientific texts.

\section{Results}

Here are the results of the survey that was conducted. In this way, on the questions regarding the familiarization of the students with the study of literary and scientific texts, a good familiarization of the students with study techniques both for literary texts, as well as scientific texts can be noticed: $80 \%$ (93 of respondents) master study techniques for literary texts and over $60 \%$ (67 of the students) know study techniques for for scientific texts. Out of the students that were questioned, over $8 \%$ (9students) are not familiar with study techniques for literary texts and $14,78 \%$ (17 students) for scientific texts. 9,56\% (11 students) don't know if they are familiar with study techniques for literary texts and 18,26\% (21 students) for scientific texts. The results appear in the graphic below: 
The familiarization of students with study strategies for the literary and scientific text

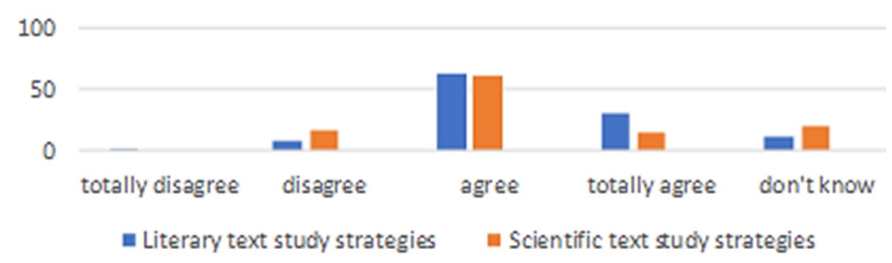

Figure no. 1. A comparative representation of the degree of familiarization of students with study techniques for literary and scientific texts

To the question I prefer the classical methods of teaching (based on the explanation of new notions) instead of the methods that emphasize the discovery of the notions by studying the text, the option of students for the teaching methods was the following: approximately $70 \%$ - over 80 students - prefer the classical methods of teaching, based on the explanations of the teacher, and over $20 \%$ ( 25 students) prefer the study of the text for the discovery of new information. 7,82\% (9 students) have opted for the option I don't know.

I prefer the classical methods of instead of the methods that emphasize the discovery of the notions by studying the text

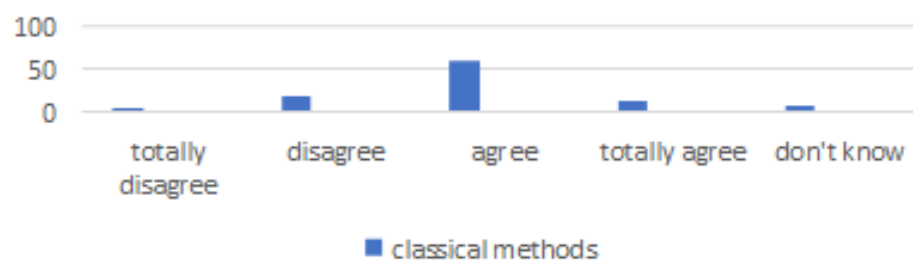

Figure no 2. The option of students for the methods based on explanation or the methods based on studying the text

Among the difficulties encountered by students in studying the texts, a very large number of choices was for the difficult specialty terms $-59,13 \%$, specialty terms in great number - 37,39\% (43 students), long texts and a complex language are equally difficult for approximately $27 \%$ (31 students). $6,95 \%$ (8 students) don't encounter difficulties.

When learning a new lesson, the difficulties that are encountered by students are: the patience to go through the text integrally $45,21 \%$ (52 students); the identification of the key notions, as well as the communication to the others of the learned notions are considered to be difficult for the same number of students $21,73 \%$ ( 25 students); the formulation of the main ideas and the association of the new notions with other learned notions represent difficulties for over $12 \%$ of the students (12, respectively 14 students). $20 \%$ of the questioned students don't encounter difficulties in learning (23 students).

To the questions I consider it is important to know techniques in order to study a scientific text, the answers were formulated in the following manner: complete agreement $-33,91 \%$ (39 students), agreement $-52,17 \%$ (60 students), disagreement - 2,60\% (3 students), complete disagreement $0,86 \%$ ( 1 student) and don't know $-10,43 \%$ (12 students).

\section{I consider it is important to know techniques in order to study a scientific text}

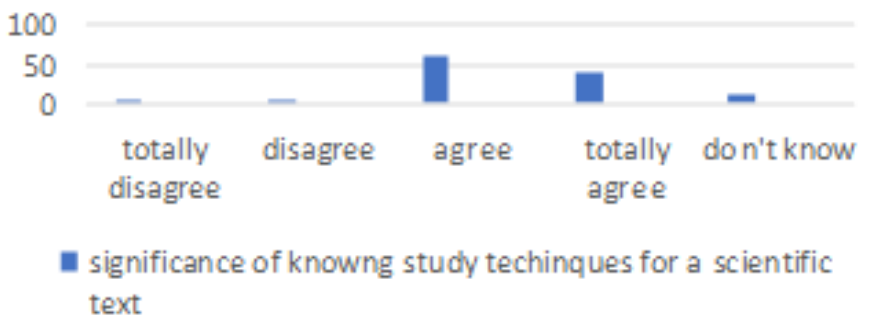

Figure no 3. The opinion of the students about the significance of knowing the study techniques for a scientific text

Conclusively, the importance of knowing the study techniques for a scientific text is pointed out by over $85 \%$ of the respondents ( 99 students), approximately 3\% of the students (4 students) don't consider these study techniques necessary and 10,43\% (12 students) don't know whether knowing the study techniques for a scientific text is important to them.

\section{Discussions}

By analyzing the results that were obtained after the survey was applied on the 10th grade students regarding the study techniques of the texts, so the literacy abilities, we can notice a good mastery of the study techniques of both the literary and the scientific texts. The study techniques of the literary texts are mastered by a larger percent of the respondents (over 80\%), while the literacy abilities for scientific texts are familiar to approximately $60 \%$ of the students. Even if the percentage is great, the differences between the obtained results may be the result 
of the manner in which the teaching activity is unfolded: in Romanian classes and/or foreign languages, strategies based on text analysis are predominant, while in science classes (Physics, Biology, Chemistry, Maths etc.), the teaching-learning activity is organized predominantly through strategies based on explaining the notions by a teacher or presenting these strategies in the final form, and the use of text study is rarely encountered. This result can easily be correlated with the preference of the students for strategies based on the teacher's explanations, an option that is expressed by the students to the third question, in the detriment of the literation strategies that are particular to the scientific text. This preference can be determined by many causes: a lack of exercise in the analysis of a scientific text can make this activity extremely complex and discouraging, the certainty that they found out the correct information, without the risk of understanding the text wrongfully, the convenience expressed by the desire of not putting the effort into learning; obtaining scientific information presented in a concise manner, it simplifies the effort put by the student in learning. But these aspects are not beneficial in forming one's own style of learning, so the formation of literacy abilities for a scientific text is extremely important.

Questions 4 and 5, respectively, show the numerous difficulties encountered by the students in studying scientific texts and in learning a new lesson. So, even if the students claim that they are familiarized with study techniques for the texts, many of the enumerated difficulties indicate that literation abilities are insufficiently formed. One cause of the difficulties encountered by the students might be the large quantity of information that is transmitted in a teaching activity and, due to an overcharged school curriculum, the time for fixating new knowledge is extremely limited. Therefore, the new notions are not connected with the notions that are already assimilated, the moment of applicability or transposition in practical situations of the studied notions is lost. In this way, important stages of literation's are lost. The difficulties that were encountered by the students both in studying of a scientific text, but also in studying new notions can lead to a lack of motivation for studying, and the lack of motivation can have as a consequence a lack of formation of learning strategies to be applied in one's own learning.
The students who don't know whether these techniques are important or not are not to be neglected, but also the ones who claim that these are not important. Even if they comprise a very small percentage, these students didn't manage to become aware of the role of deschipering a written text in one's own learning, as well as the application of literacy in daily life, so it requires an increased attention from the teachers.

It should be noticed that the majority of students consider knowledge and the application of particular study techniques for the scientific text to be very important. This results in the importance that they offer to studying the texts and this aspect contributes to the formation of the literacy abilities, respectively of the abilities for individual study.

\section{Conclusions}

At the end of the research, some conclusions have appeared:

- The presented research points out the fact that students know and appreciate the particular elements of literation abilities.

- $\quad$ The learning to learn competence is based on the skill of the youngster to possess literation abilities in order to form abilities for individual study that can be applied in the personal and professional development. So, at the end of mandatory schooling, it can be stated that these youngsters have literacy abilities, thus envisaging a delightful situation, that of overcoming functional illiteracy.

- The students that were involved in the presented study, by becoming aware of the fact that they hold study abilities for the texts are ready with the necessary skills to form the learning to learn competence.

- $\quad$ Recognizing the difficulties in learning represents an important stage in forming of the learning to learn competence because it is an awareness of a problem that can be fixed. This aspect denotes the preoccupation of the students for forming effective study techniques. 
- It would be interesting to correlate the answers of the students with the obtained results to the PISA tests, considering they are a generation of students who took the exam in 2015. In this way, the differences in evaluation and self-appreciation/selfevaluation can be analyzed, but also the evolution along the three years.

- Also, the research can be extended to the teachers who teach these classes in order to have a double perspective on the appreciation of the level of literation that was achieved.

- The value of the research resides in showing the literacy abilities formed in 10th grade students, as well as the difficulties encountered by them in learning.

- $\quad$ As limits are concerned, it can be noticed that the dimension of the group of respondents doesn't enable the generalization of the result of the research over the entire school population, on a national level.

Literation abilities are an essential element in developing strategies for individual study that are necessary in the formation of the learning to learn competence.

\section{Authors note:}

Nicoleta Meseșan is Ph.D. student, Doctoral School "Education, Reflection, Development", Faculty of Psychology and Educational Sciences.

\section{References}

Adler, M.J., Van Doren, Ch. (2016). Cum se citește o carte. Ghidul clasic pentru o lectură inteligentă. Pitești: Editura Paralela 45.

Bocoş, M.-D. (coord.), Răduţ-Taciu, R., Stan, C., Chiș, O., Andronache, D. (2015). Dicţionar praxiologic de pedagogie. Volumul I: A-D. Piteşti: Paralela 45 Publishing House.

*** Recomandarea Parlamentului și a Consiliului European 18.12.2006 privind competențele-cheie pentru învățarea pe tot parcursul vieții. In Official Journal of the European Union, 30.12.2006 (https://eur-lex.europa.eu/legalcontent/RO/TXT/?uri=celex:32006H0962).

*** Rezultatele elevilor români la testarea OECD-PISA 2015 (https://www.edu.ro/rezultatele-elevilor-romani-latestarea-oecd-pisa-2015).

https://www.oecd.org/.../8\%20-\%20How\%20PISA. https://www.britannica.com/search?query=literacy.

\section{Appendix:}

Survey regarding the formation of the literation strategies in students:

Dear students,

Please answer the questions below by selecting the answers that best describe your learning ability:

1. I am familiar with the study strategies of a literary text:

\begin{tabular}{|c|c|c|c|c|}
\hline $\begin{array}{l}\text { Complete } \\
\text { disagreement }\end{array}$ & Disagreement & Agreement & Complete agreement & I don't know \\
\hline 1 & 2 & 3 & 4 & 5 \\
\hline
\end{tabular}

2. I am familiar with the study strategies for a scientific text:

\begin{tabular}{|c|c|c|c|c|}
\hline $\begin{array}{l}\text { Complete } \\
\text { disagreement }\end{array}$ & Disagreement & Agreement & Complete agreement & I don't know \\
\hline 1 & 2 & 3 & 4 & 5 \\
\hline
\end{tabular}

3. I prefer the classical methods of teaching (based on explaining the new notions) instead of the methods that emphasize the discovery of the notions by studying the text: 


\begin{tabular}{|c|c|c|c|c|}
\hline $\begin{array}{l}\text { Complete } \\
\text { disagreement }\end{array}$ & Disagreement & Agreement & Complete agreement & I don't know \\
\hline 1 & 2 & 3 & 4 & 5 \\
\hline
\end{tabular}

4. When I read a scientific text, I encounter the following obstacles/ difficulties:
a) Numerous specialty terms;
b) Difficult specialty terms;
c) Long texts;
d) Complex phrasing;
e) I don't encounter difficulties.

5. When learning a new lesson, it is very difficult:
a) To formulate the main ideas;
b) To select the key concepts;
c) To associate new notions with other learned notions;
d) To communicate the new concepts to the other ones;
e) To have the patience to go through the recommended material;
f) I don't encounter difficulties.

6. I consider it is very important to know study techniques in order to study a scientific text.

\begin{tabular}{|c|c|c|c|c|}
\hline $\begin{array}{l}\text { Complete } \\
\text { disagreement }\end{array}$ & Disagreement & Agreement & Complete agreement & I don't know \\
\hline 1 & 2 & 3 & 4 & 5 \\
\hline
\end{tabular}

Grade

Age 